\title{
FUNÇÕES REGULATIVAS EM KANT E NIETZSCHE
}

\author{
Márcio José Silveira Lima* \\ mjslima@ufba.br
}

RESUMO A presença de Kant e possível influência na filosofia de Nietzsche é motivo de muita controvérsia. Se em seus primeiros escritos Nietzsche é claramente influenciado por Kant, os textos do período maduro não deixam perceber com clareza o teor do diálogo que neles se estabelece, uma vez que Nietzsche assume uma postura radical contra Kant. Essa postura esconde justamente que, em meio aos rompimentos diante do idealismo transcendental, Nietzsche permanece devedor de Kant. Um aspecto dessa divida é a noção de ficção regulativa. Pretendemos, assim, mostrar, primeiramente, que a concepção de Nietzsche de que a falsidade de um juízo não constitui uma objeção contra ele é um traço decisivo de seu pensamento antidogmático e, em seguida, defender que esse antidogmatismo tem ascendência na concepção de Kant de princípios regulativos.

Palavras-chave Kant, Nietzsche, princípios regulativos, ficções regulativas.

ABSTRACT The presence of Kant and its possible influence in Nietzsche's philosophy is a controversial issue. If in his early writings Nietzsche is clearly influenced by Kant, his mature period texts no longer allow anyone to see clearly the content of the dialog established therein, once Nietzsche assumes a radical view against Kant. This view hides that, regardless the disruptions done in face of the transcendental Idealism, Nietzsche remains debtor to Kant. An aspect of this debt is the notion of regulative fiction. We

* Professor da UFBA. Artigo recebido em 31/07/2013 e aprovado em 08/11/2013.

KRITERION, Belo Horizonte, no 128, Dez./2013, p. 367-382 
intend, thus, to show: first, that Nietzsche's conception that the falsity of a judgment does not constitute an objection to itself is a decisive trace of his anti-dogmatic thought and, secondly, to argue that this anti-dogmatism has ascendancy in Kant's conception of regulative principles.

Keywords Kant, Nietzsche, Regulative principles, Regulative fiction.

Kant figura como umas das presenças mais constantes na obra de Nietzsche. Habermas e Foucault, dois dos mais influentes pensadores contemporâneos, interpretam de forma oposta a relação entre os dois filósofos. Habermas elege Nietzsche como um ponto de inflexão no projeto racionalista da modernidade inaugurado por Kant. Embora se atenha ao espírito geral do projeto de transvaloração de todos os valores, a letra nietzschiana em que se apoia para apresentar os elementos constitutivos daquela viragem é a das primeiras obras, quando a invocação a uma cultura dionisíaca se fazia ouvir sob os ecos da filosofia crítica kantiana. ${ }^{1}$ Foucault, por sua vez, na interpretação da "Antropologia" de Kant, considera que toda filosofia posterior e as ciências humanas confrontaram a questão kantiana "Was ist der Mensch?". Situada entre uma crítica cuja resposta à pergunta prescinde do absoluto, mas conserva o caráter transcendental do a priori, a antropologia kantiana teria aberto o caminho ou para uma ilusão antropológica de uma ciência do homem que não compreendeu a dimensão da resposta kantiana ou de filosofias que não superaram o problema da subjetividade, mas nela se fecharam. Em ambos os casos, haveria uma ilusão antropológica ou de um mal-entendido da crítica kantiana ou de um subjetivismo em que a verdade do homem é o espelho para a verdade mesma. Em conjunto, essas duas vertentes teriam interditado a tarefa de uma crítica à ilusão antropológica, caminho aberto apenas por Nietzsche com o Übermensch. ${ }^{2}$

Se a interpretação de Habermas concentra-se nas ideias do jovem Nietzsche e a de Foucault nas obras tardias, é ainda possível interpretar a influência de Kant desde outra perspectiva, seguindo os passos dessa influência ao longo do trajeto do pensar nietzschiano. De fato, questões e problemas importantes com que se ocupa Nietzsche e nos quais se pode perceber alguma

1 Justamente Habermas, que se vale amiúde da ideia de contradição performativa, considera Nietzsche o primeiro filósofo a confrontar radicalmente o projeto moderno iniciado com Kant, baseando sua análise precisamente nas obras de Nietzsche em que a influência kantiana era explícita. Para a interpretação geral de Habermas sobre Nietzsche, assim como sobre a noção de contradição performativa, cf. Habermas (2002, pp. 121-151, 170, 182, 261-262).

2 Cf. Foucault, 2011, pp. 106-111. 
filiação kantiana aparecem desde os primeiros livros. Ainda mais: talvez devêssemos considerar concepções ulteriores da obra de Nietzsche como sendo uma resposta mais elaborada a problemas herdados de Kant e para os quais Nietzsche não conseguiu oferecer soluções próprias nas primeiras obras. Há pelo menos duas formas como Nietzsche lida com a filosofia de Kant em seus primeiros escritos. Por um lado, ele se apropria de pressupostos kantianos sob várias perspectivas para erigir aquilo que serão seus alicerces. Esse tipo de posicionamento aparece com muita clareza em obras como "O nascimento da tragédia" e "A filosofia na época trágica dos gregos" e de forma menos intensa em "Sobre verdade e mentira no sentido extramoral". Por outro lado, encontramos um outro tipo de postura, isto é, um posicionamento mais distante, comumente marcado por uma crítica moderada a princípios fundamentais da filosofia crítica. Quase sempre, essas duas tendências implicam contradições do pensamento de Nietzsche, e ele próprio entoará um lamento por isso. ${ }^{3}$

A partir de seus livros intermediários, Nietzsche adota outra postura. Não assume deliberadamente a apropriação que faz da filosofia de Kant, que passa a ser menor, é bem verdade, atitude que se converte na crítica radical de suas obras. Ora, o tom dessa crítica esconde justamente a permanência da presença kantiana em seu pensamento, o que acaba por dificultar a visão de que a influência não apenas permanece, como é ainda mais forte do que Nietzsche gostaria de admitir, pois se enraíza desde os primeiros livros. A concepção de ficção regulativa revela bem a presença da filosofia de Kant na obra de Nietzsche, sem, no entanto, deixar transparecer-se com muita evidência. Essa presença, como veremos, sugere uma relação especular entre os dois filósofos, existente desde as primeiras obras, cuja versão final seria o desenvolvimento e a coroação de um processo.

$\mathrm{Na}$ arquitetônica kantiana, entre suas várias divisões e subdivisões, a cisão entre coisa em si e fenômeno será claramente decisiva para a filosofia de Nietzsche, mas de modo nada explícito a diferença entre princípios constitutivos [constitutives Princip] e princípios regulativos [regulatives Princip] e entre uma lógica da verdade [Logik der Wahrheit] e uma lógica da aparência [Logik des Scheins] também causou grande impacto no pensamento nietzschiano, os quais, por sua vez, integram a dissolução promovida pela distinção entre o que é teórico e o que é prático. No âmbito da "Crítica da

3 Na autocrítica que acrescenta à edição de 1886 de "O nascimento da tragédia", Nietzsche lamenta que não tinha ainda uma linguagem própria quando escreveu sua obra sobre a tragédia, daí ter se utilizado de expressões kantianas e schopenhauerianas (Cf. Nietzsche, 1967/1978, "O nascimento da tragédia" [NT], ensaio de autocrítica § 6, KSA I, p. 19). 
razão pura", os aspectos práticos são reservados às partes finais da obra, especialmente à dialética transcendental, num movimento que primeiro apresenta as condições teóricas para a possibilidade de um conhecimento objetivamente válido para, em seguida, vetar que um conhecimento desse tipo seja possível quando se trata dos objetivos da metafísica clássica, como Deus, alma e mundo, ou Deus, imortalidade e liberdade. Apesar de limitar o alcance da razão especulativa, Kant considera que, no domínio prático, tais ideias são imprescindíveis. Problema que encontra uma explicação condensadíssima na célebre passagem segundo a qual Kant teve de "suprimir o saber para encontrar lugar para a crença". ${ }^{4}$

Percurso diferente do de Kant fará Nietzsche ao analisar o problema do conhecimento desde uma perspectiva moral, considerando que as categorias com que a filosofia tradicionalmente se ocupa em sua busca por fundamentação e justificação da verdade têm uma procedência no terreno valorativo da moral. Segundo o texto de juventude - mas cuja importância no que tange ao problema do conhecimento e da verdade é imprescindível no conjunto da obra nietzschiana - "Sobre verdade e mentira no sentido extramoral", o pathos da verdade, isto é, a necessidade humana de crer em coisas eternas, não sujeitas ao criar-se e destruir-se próprio do vir a ser, é antes de tudo uma necessidade introjetada no intelecto humano a partir do convívio social. Como Nietzsche afirma num fragmento póstumo, apenas com Sócrates a veracidade [Wahrhaftigkeit] se apodera da lógica. ${ }^{5}$

No texto de 1873, Nietzsche assume a distinção kantiana entre coisa em si e fenômeno, tomando aquele como um conceito-limite, ${ }^{6}$ um X desconhecido ao qual o intelecto jamais poderia conhecer a essência. Da perspectiva fenomênica, no entanto, será outra a postura em relação ao legado kantiano. A princípio, Nietzsche concorda com a idealidade do pensamento, todavia não assume a dedução kantiana das intuições sensíveis e das categorias. É por meio de uma concepção retórica que Nietzsche pensa a organização idealista do mundo fenomênico. O intelecto só pode manter com o mundo e seus objetos um tipo de relação mediada por uma capacidade retórica da linguagem, especialmente por meio da metáfora. Nesse ponto, Nietzsche

4 Kant, 2001, B XXX, p. 27.

5 Cf. Nietzsche, 1967/1978, "Fragmento póstumo" 19 [216] do verão de 1872-começo de 1873, KSA 7, p. 286.

6 Cf. Kant, 2001, B 311, p. 270. 
insere no idealismo transcendental de que está se apropriando um elemento inteiramente novo. ${ }^{7}$

Resgatando a noção aristotélica de metáfora como transposição, ${ }^{8}$ Nietzsche considera a impossibilidade de o pensamento corresponder aos objetos justamente porque o meio que teria para tanto, ou seja, a linguagem, só é capaz de basear-se em metáforas, nunca numa expressão adequada [adäquaten Ausdruck]. ${ }^{9}$ Analogamente a Kant, que parte dos juízos lógicos para deduzir as categorias do entendimento, Nietzsche parte de figuras retóricas da linguagem para associar a própria estrutura linguística às capacidades cognitivas. É a conhecida tese nietzschiana de que a palavra resulta de um processo em que um estímulo nervoso se transpõe em uma imagem e esta, por seu turno, se modela em um som..$^{10}$ A transposição, portanto, está incrustada na forma mesma como o intelecto humano pensa e transpõe seus pensamentos na linguagem.

Todavia, quando tudo parecia conduzir Nietzsche a uma apropriação de Kant em que lhe infligisse uma radicalização do projeto crítico de combate ao dogmatismo, vemo-lo assumir noções do idealismo transcendental que pareciam superadas. Na tese retórica de que o pensamento só dispõe de metáforas para referir-se às coisas, Nietzsche considera que uma tal visão sobre o intelecto resvala em um subjetivismo perigoso, pois a transposição originária que revela o modus operandi do intelecto não assegura que as percepções sejam as mesmas para distintos homens. Para que o mundo não seja uma criação extremamente subjetiva [ein höchst subjectives Gebilde], ${ }^{11}$ deve haver algo que assegure a regularidade com que o homem percebe os fenômenos da natureza. Para tanto, Nietzsche considera que tempo, espaço, causalidade e números, portanto, aquela interação entre intuição e conceitos, asseguram uma forma universalmente válida com que o homem apreende o mundo de maneira objetiva. Nietzsche não resolve o dilema de adotar uma concepção retórica da linguagem que substitui o caráter transcendental do pensamento, ao mesmo tempo que subsume aspectos essenciais desse mesmo idealismo em sua teoria retórica da linguagem. Com efeito, ele primeiro afirma que o conceito não tem nenhum fundamento seguro, pois é uma metáfora que

7 Para uma interpretação da visão de Nietzsche sobre a linguagem em suas primeiras obras, bem como para a questão da retórica e do conhecimento nelas, cf. Crawford (1988, pp. 199-220), Lopes (2006, pp. 25-64) e Clark (2002, pp. 63-93).

8 Cf. Aristóteles, 1987, 1457 b 6, p. 220.

9 Cf. Nietzsche, 1967/1978, "Sobre verdade e mentira no sentido extramoral" [VM], § 1, KSA 1, p. 875.

10 Cf. Nietzsche, 1967/1978, p. 879.

11 Ibidem, p. 885. 
se esqueceu de que o é, para depois considerar que o conceito de causalidade e a relação categorial de quantidade asseguram um conhecimento objetivo dos fenômenos.

O maravilhoso, o que precisamente nos assombra das leis da natureza, o que exige nossa explicação e o que poderia introduzir em nós a desconfiança acerca do idealismo, reside única e exclusivamente no rigor matemático e na inviolabilidade das representações do espaço e do tempo. Com efeito, produzimos em nós e a partir de nós essas noções com a mesma necessidade que a aranha tece sua teia; se estamos obrigados a conceber todas essas coisas por meio dessas formas, então não é nenhuma maravilha que, a bem da verdade, só percebamos em todas as coisas precisamente essas formas, pois todas elas devem levar consigo as leis do número, e o número é precisamente a mais assombrosa das coisas. ${ }^{12}$

Soa estranha essa aceitação de Nietzsche das formas a priori. Em grande parte de seu texto, o filósofo argumentou em prol de sua concepção retórica, defendendo a impossibilidade de haver uma adequação entre o pensamento e as coisas. O próprio conceito, nessa perspectiva, é uma metáfora apagada, e como tal, esqueceu-se de sua proveniência. Se a concepção retórica da linguagem conduz a um relativismo cognitivo, a saída que Nietzsche encontra para esse problema é assumindo a capacidade de as formas a priori, entre elas a do conceito, organizarem a experiência a partir de uma validade objetiva. Talvez Nietzsche fizesse uma distinção entre conceitos empíricos e puros, pois sugere que o conceito esconde sua ascendência metafórica quando perde a referência imediata às coisas. Haveria, assim, a possibilidade de existirem conceitos puros, o de causalidade e o de números, por exemplo, que escapariam às condições retóricas, isto é, não seriam o resultado daquele processo de transposições, mas independente deles. Todavia, ele não faz essa distinção, apenas refere-se aos conceitos de um modo geral. Assim, todo conceito tem ascendência numa metáfora, embora pela passagem acima não seja esse o argumento.

A partir de "Humano, demasiado humano", Nietzsche começa a desenvolver uma concepção de conhecimento com os mesmos pressupostos naturalistas de antes, mas já livres dos aspectos do idealismo transcendental que estavam presentes nas primeiras obras. Um problema central, porém, que orienta essa nova dimensão cognitiva refere-se precisamente ao da unidade, ou seja, de como é possível a unidade do conceito e sua forma de organizar a multiplicidade dada na experiência. Segundo sua nova concepção, o homem 
herdou de formas primitivas do organismo sua capacidade para relacionarse com o mundo exterior [Aussenwelt]. Por isso, sua estrutura cognitiva é o resultado de mecanismos atávicos de organismos inferiores. Desses organismos, o intelecto humano traz ainda a marca de quem avalia e se apropria do mundo circundante pelos crivos do prazer e da dor. A noção de identidade está inscrita no homem desde os primórdios, na medida em que toda a diversidade era reduzida a uma espécie de identidade. As diferenças individuais são suprimidas, restando apenas uma relação em que se foge da dor e se busca o prazer. ${ }^{13}$ Recurso necessário para fins de sobrevivência, essa redução da multiplicidade à unidade resulta do mesmo procedimento a que Nietzsche chamará de vontade fundamental do espírito [Grundwillen des Geistes], que é uma força para apropriar-se do que é estranho por meio de uma assimilação do novo ao antigo, de uma simplificação do complexo e de uma rejeição do inteiramente contraditório. Portanto, cada fragmento do mundo exterior tem de ser sublinhado e destacado, pois, na luta por sobrevivência, a agilidade da simplificação do diverso pode ser decisiva para organismos que precisam viver, crescer e multiplicar-se. ${ }^{14}$

Em "Sobre verdade e mentira", podemos considerar que Nietzsche não consegue atingir sua meta, que é demonstrar que as questões epistêmicas são, no fundo, problemas morais. Se a verdade é uma exigência valorativa moral para o bom funcionamento social e só tardiamente ela adentra o reino da lógica e do conhecimento, ao preservar um tipo de conhecimento conceitual livre do processo metafórico, o jovem Nietzsche acabou por abrir uma fissura em sua própria teoria. Ora, se a linguagem como metáfora revelava ser o impulso à verdade o resultado de uma mera convenção social, o relativismo a que essa tese conduziu obrigou o filósofo a assumir a existência de uma estrutura categorial que escapava à sua contraposição à verdade. A linguagem, de acordo com o naturalismo defendido a partir de "Humano, demasiado humano", guarda o caráter utilitário da própria estrutura orgânica do homem. Se na luta por sobrevivência o processo de simplificação e abreviação é decisivo para a manutenção de uma espécie como a humana, a linguagem representa um componente que é a expressão mesma dessa luta.

Toda a engrenagem linguística que a metafísica opera daria testemunho disso. Os princípios supremos, como o de não contradição e o de identidade, seriam frutos daquele procedimento útil às espécies de não perceber o diferente, o contraditório, dado que isso implica uma simplificação de um 
mundo que precisa ser dominado. Da mesma forma, os conceitos de espaço, tempo, causalidade, número, substância etc. seriam formas perspectivas [perspektivische Formen], em que se reduz a multiplicidade à simplicidade como recurso de sobrevivência. ${ }^{15} \mathrm{E}$, por fim, as dicotomias, como, por exemplo, sujeito e objeto, coisa em si e fenômeno, mundo sensível e mundo inteligível, seriam resultado de uma estrutura gramatical da linguagem da qual não se pode escapar. A história da filosofia como um todo, com raras exceções, ${ }^{16}$ daria testemunho de um desenvolvimento da linguagem em torno de um jargão metafísico que tenta negar a efetividade [Wirklichkeit]. Daí a sentença de Nietzsche de que não nos livraremos de Deus enquanto acreditarmos na gramática. ${ }^{17}$

Essa versão naturalista das faculdades do conhecimento e da linguagem a elas associada permitirá a Nietzsche finalmente elaborar uma crítica mais contundente da verdade, remetendo-a para o âmbito valorativo, sem com isso cair numa espécie de relativismo, tal como acontece em "Sobre verdade e mentira". Com efeito, a linguagem desenvolve-se no homem por causa de uma necessidade de comunicação [Mitteilungs-Bedürftigkeit], e a favor dessa necessidade trabalharam as capacidades fisiológicas, simplificando o complexo e rejeitando o inteiramente contraditório. Dessa simplificação já faz parte o processo mesmo de interpretação dos estados internos para fins de comunicação e manutenção da espécie. Uma concepção assim de linguagem já desmascara como crença as categorias da razão e as faculdades de conhecimento que lhe dão suporte. $\mathrm{E}$ os signos com que a linguagem metafísica se exprime já não operam no âmbito da verdade, antes expressam crenças necessárias à vida de uma espécie. Em "A gaia ciência”, no parágrafo 354, Nietzsche afirma:

Não é, como se adivinha, a oposição de sujeito e objeto que me importa aqui: deixo essa distinção aos teóricos do conhecimento, que ficarão presos na malha da gramática (a metafísica do povo). E nem é bem a oposição entre "coisa em si" e "fenômeno": pois estamos longe de "conhecer" o bastante para sequer podermos separar assim. Não temos, justamente, nenhum órgão para o conhecer, para a "verdade"; "sabemos" (ou acreditamos ou imaginamos) precisamente o tanto que, no interesse do rebanho humano, da espécie, pode ser útil: e até mesmo o que aqui é denominado "utilidade"

15 Cf. Nietzsche, 1967/1978, "Fragmento póstumo" 40 [39] de agosto-setembro de 1885. KSA, 11, 648/649 e HH § 19, KSA 2, pp. 40-41.

16 No contexto de "O nascimento da tragédia", Nietzsche chama de sabedoria trágica a não negação do caráter perecível da efetividade. Nesse sentido, afirma, em "Ecce Homo", que sentia alguma proximidade em Heráclito. Cf. Nietzsche, 1967/1978, "Ecce Homo" [EH], "O nascimento da tragédia" § 3, KSA 6, p. 312.

17 Cf. Nietzsche, 1967/1978, "Crepúsculo dos ídolos" [CI], A razão na filosofia, § 5, KSA 6, p. 78. 
é, por último, simplesmente uma crença, uma imaginação, e talvez precisamente aquela estupidez a mais fatal de todas, de que um dia sucumbiremos. ${ }^{18}$

Nietzsche considera então que, a serviço da vida, a linguagem é incapaz de desvendar uma verdade sobre as coisas. Isso seria possível se tivéssemos um órgão para a verdade; mas, destituídos de tal órgão, tanto as faculdades do conhecimento quanto a estrutura gramatical de onde os teóricos do conhecimento retiram sua crença na verdade estão envolvidas num processo complexo de procedimentos de uma vontade de potência que atua em favor da vida. Onde os dogmáticos, com sua vontade de verdade, acreditam descobrir a verdade, Nietzsche enxerga interpretações úteis, perspectivas, óticas de fechada, e erros que têm valor regulativo. E é precisamente nesse ponto que Nietzsche reencontra Kant, especialmente na distinção que este faz entre uma lógica da verdade e uma lógica da aparência e em sua divisão correlata entre princípios constitutivos e princípios regulativos.

De acordo com Kant, as leis da natureza submetem às regras os objetos da experiência mediante princípios que têm validade $a$ priori e são anteriores a toda experiência. ${ }^{19}$ Kant divide os princípios do conhecimento em quatro modalidades, de acordo com as quatro formas gerais das categorias. Axiomas da intuição, antecipações das percepções, analogias da experiência e postulados do pensamento empírico em geral. Os dois primeiros seriam matemáticos, pois são os princípios que demonstram a necessidade matemática para que toda experiência possível possa tornar-se conhecimento objetivamente válido. Os dois últimos dinâmicos, isto é, físicos, pois não se limitam à aplicação matemática como também afirmam a existência de objetos. Como os princípios constitutivos contêm as condições a priori para as intuições puras, eles são apodíticos; os regulativos, porque só têm o caráter de necessidade mediante uma experiência possível, têm sua validade universal dada de forma mediata, em função de sua dependência com os objetos. Por isso, eles não constituem as aparências fenomênicas, antes contêm as regras pelas quais podem ser reguladas. ${ }^{20} \mathrm{O}$ que ressoará no pensamento de Nietzsche é a forma como Kant pensa os princípios regulativos na esfera da metafísica e em sua importância para a razão prática.

18 Nietzsche, 1996, "A gaia ciência", 354, p. 202, KSA 3, 593.

19 Cf. Kant, 2001, B 198, p. 195.

20 Como argumenta Allison, Kant considera que, dados três termos, é possível descobrir o quarto, mediante uma regra para buscá-lo na experiência. Todavia, o que a analogia oferece é uma regra para encontrar o quarto termo, mas não oferece o termo ele mesmo. Isso distingue a analogia matemática da filosófica. Por isso, ele caracteriza esses princípios de regulativos e não constitutivos (Cf. Allison, 2004, p. 226). 
Kant denomina de lógica da verdade sua analítica transcendental, pois nela se demonstram as condições de possibilidade a priori de um conhecimento sensível com validade universal e objetivo. Ali se demonstra também como são possíveis os juízos sintéticos a priori, ou seja, pela interação entre os conceitos e a intuição. Assim, a lógica da verdade pressupõe que os conceitos a priori do entendimento passam por uma síntese com as intuições sensíveis. A dialética transcendental, dedicada à metafísica especial, será denominada de lógica da aparência. Ao contrário do conhecimento objetivo e verdadeiro, tem-se aí um conhecimento aparente.

O resultado de todas as nossas tentativas dialéticas da razão pura não só confirma o que provamos na Analítica Transcendental, a saber, que todos os nossos raciocínios que pretendem levar-nos para além do campo da experiência possível são ilusórios e destituídos de fundamento, mas também nos esclarece esta particularidade, que a razão humana tem um pendor natural para transpor essa fronteira e que as ideias transcendentais são para ela tão naturais como as categorias para o entendimento, embora com a diferença de as últimas levarem à verdade, isto é, à concordância dos nossos conceitos com o objeto, enquanto as primeiras produzem uma simples aparência, embora inevitável, cujo engano mal se pode afastar pela crítica mais penetrante. $^{21}$

Por um procedimento ilegítimo, a razão se utiliza dos conceitos do entendimento, embora não lhes dê um uso empírico, mas hiperfísico. ${ }^{22} \mathrm{Se}$, por um lado, a dialética transcendental é uma lógica da aparência justamente porque desmascara o uso ilegítimo que a razão faz das categorias, por outro, a validade desse uso será assegurada. Se os princípios de um conhecimento assim não têm valor constitutivo para os objetos da experiência, eles têm valor prático na medida em que regulam as ações humanas na esfera moral. Em nosso entender, essa concepção é de extrema importância para a filosofia de Nietzsche e, como será retomada em toda sua amplidão no último período de sua obra, ficará sotoposta às suas diatribes contra Kant.

Ao desconsiderar a existência de um órgão para a verdade, Nietzsche contrapõe-se à ideia de um mundo verdadeiro e por consequência de um mundo aparente. Tal distinção é fruto daquela gramática a que está sujeito o pensar. Nietzsche rejeita a distinção kantiana entre lógica da verdade e lógica da aparência, princípios constitutivos e regulativos, razão especulativa e razão prática. Com isso, considera todo pensamento como uma ficção útil que só pode referir-se a um mundo de aparências. Tais ficções têm apenas valor 
regulativo, estão a serviço de um organismo que precisa viver. Ora, pensar em verdade e constituição do conhecimento já é uma necessidade regulativa: o conhecimento e a ciência estão a serviço da vida. Mesmo os juízos sintéticos a priori, que Kant julga serem verdadeiros e demonstrarem como se dá a constituição do conhecimento, serem, para Nietzsche, falsos. No entanto, tais juízos têm valor porque servem à vida, ou seja, porque têm valor regulativo para o homem. A pergunta kantiana sobre a possibilidade dos juízos sintéticos a priori deve ser substituída por outra: por que eles são necessários? ${ }^{23}$

Se Kant afirma a existência de uma lógica da verdade e em princípios constitutivos, Nietzsche afirma que toda forma de pensar é um tipo de erro que tem valor como ficção regulativa. No entanto, tal compreensão é ainda devedora do próprio Kant. Senão vejamos. Como a metafísica procede de um uso ilegítimo da razão, no qual o acordo entre conceitos e intuição não acontece, segue daí uma lógica da aparência, na qual o pensamento não produz a verdade, embora dê origem a aparências que têm valor como princípios regulativos, pois têm validade para a razão prática. Se Kant afirma que, não obstante a razão produzir dialeticamente erros e aparências, seus princípios têm validade prática, Nietzsche, por seu turno, amplia essa concepção de modo a tornar seu alcance muito mais abrangente. De fato, onde Kant pensa encontrar princípios verdadeiros e objetivos, na física, por exemplo, Nietzsche afirma haver erros e interpretações, ficções úteis porque regulam a vida de modo a garantir-lhe a sobrevivência. ${ }^{24}$

Há ainda outro aspecto da noção de princípios regulativos que Nietzsche adota: conceber que os erros e aparências, porque naturais ao homem, não podem ser dissipados quando descobertos. Na dialética transcendental, Kant procura a fonte do erro [Irrtum] ou da aparência [Schein]; por uma interferência da sensibilidade sobre o entendimento, a razão acaba ultrapassando seus limites, sendo levada a conceber uma experiência possível onde nenhum objeto é dado. Essa influência acontece, na analogia kantiana, da mesma maneira quando uma força atua sobre um corpo, fazendo-o adquirir um movimento diferente daquele em linha reta a que estava destinado caso não houvesse essa colisão. Por isso, a dialética contém uma reflexão transcendental que revela como a

23 Cf. Nietzsche, 1967/1978, BM, § 11, KSA 5, p. 24/26.

24 Cf. Ibidem, p. 37. António Marques encontra no jovem Nietzsche reflexões sobre os princípios regulativos kantianos. Em 1868, em fragmentos sobre a terceira "Crítica", Nietzsche já procura circunscrever o estatuto subjetivo utilitário daquilo que para Kant ainda tem valor cognitivo puro. Já na década de 1880 , Nietzsche adota uma concepção perspectivista sobre o organismo em Kant, alargamento que depende de nossos interesses racionais ou vontades. António Marques conclui então: "por isso é que, na emergência do perspectivismo, o regulador aparece como uma primeira matriz que Nietzsche foi definindo desde logo em seu projeto de tese sobre a teleologia em Kant" (Marques, 2003, p. 59). 
sensibilidade influi no entendimento, encaminhando os juízos em direção ao erro. O erro, também denominado por Kant de aparência, não é aquele gerado na experiência, tal como ocorre nas ilusões óticas, cujo exemplo mais clássico é o do bastão de madeira posto na água e aparecendo à visão como se fosse curvo e não retilíneo. Não é essa aparência empírica que interessa, mas sim a transcendental. No primeiro caso, descoberto o erro, a razão fica em paz consigo mesma. No segundo, embora a ilusão seja descoberta, não é possível desvencilhar-se dela facilmente. Se ao longe o mar se parece mais alto, sabemos, porém, que ele não está num nível elevado. No entanto, essa ilusão não deixará de existir quando se vir o mar ao longe pelo fato de saber que ele não está acima de quem o vê. Analisar a aparência transcendental, descartando a empírica, é escrutinar o modus operandi da razão, demonstrando, assim, por que o erro provém de uma confusão entre princípios objetivos e subjetivos.

Essa diferença se assenta na distinção entre conhecer e pensar, pois, sendo a experiência o critério definidor para haver conhecimento, a razão começa a pensar por meio de princípios subjetivos quando ultrapassa a esfera dos objetos dados aos sentidos. Em vez de um conhecimento verdadeiro autorizado pelos objetos da experiência, tem-se um conhecimento aparente que os ultrapassa. O pensamento, pois, conduz a razão ao erro. Uma vez localizada a fonte dos erros, Kant diz, no entanto, que eles não deixarão de existir, como no exemplo da ilusão ótica.

A dialética transcendental deverá, pois, contentar-se com descobrir a aparência de juízos transcendentes, evitando ao mesmo tempo que essa aparência nos engane; mas nunca alcançará que essa aparência desapareça (como a aparência lógica) e deixe de ser aparência. ${ }^{25}$

É uma inclinação natural da razão humana conduzir o pensamento para além das fronteiras da experiência. E Kant formula o princípio lógico segundo o qual essa operação é efetuada: "o princípio próprio da razão em geral (no uso lógico) é encontrar, para o conhecimento condicionado do entendimento, o incondicionado pelo qual se lhe completa a unidade". ${ }^{26}$ Por um procedimento lógico ilegítimo, a razão parte da série dada na experiência em busca do incondicionado e do absoluto que fundamente toda experiência possível. Tentar encontrar para a série condicionada um incondicionado é raciocinar de modo a sair da profusão dos juízos do entendimento até chegar aos poucos princípios supremos da razão. Como os erros da razão se estribam 
em sua tentativa de ultrapassar a experiência e sua multiplicidade dada na série dos fenômenos, Kant denominará essa necessidade da razão de princípio de economia. Mas a dialética transcendental não é apenas um instrumento da "Crítica" para desvendar a fonte do erro; a ela também cabe analisar, uma vez feita a descoberta, qual a legitimidade dessas ideias pensadas pela razão.

Essas ideias são justamente aquelas de cuja existência se ocupa a metafísica especial. Assim, alma, mundo e Deus são as ideias a que a razão naturalmente chega após transcender logicamente a experiência, partindo da série condicionada em busca do incondicionado, de acordo com o princípio de economia. Nesse sentido, o filósofo escrutina como as três áreas da metafísica especial, psicologia, cosmologia e teologia, estão baseadas num uso dialético ${ }^{27}$ da razão, gerando apenas aparências, que, no entanto, têm valor para a razão prática. Com efeito, ainda que Deus, liberdade e imortalidade estejam excluídos da esfera do conhecimento, esses conceitos são fundamentais para pensar a moral e fundamentar a ação humana.

Do movimento que vai da analítica à dialética transcendental, podemos destacar duas consequências decisivas para a filosofia de Nietzsche. É o caso da demonstração da impossibilidade do conhecimento do mundo em si e a compreensão de que, mesmo os objetos tradicionais desse mundo não podendo ser conhecidos de acordo com a verdade, eles podem ser pensados e, com isso, guiarem a ação ética do homem. Em Nietzsche, a relação dessas duas esferas converte-se na concepção de que a falsidade de um juízo não constitui contra ele nenhuma objeção. ${ }^{28}$ Em si mesmas, essas teses revelam o passo além que Kant dá em relação à filosofia dogmática. Com efeito, já é um enfraquecimento da vontade de verdade considerar que os princípios oriundos da razão têm validade, ainda que não estejam de acordo com a verdade. Portanto, o que Kant concebe é que a verdade não é determinante para a esfera prática. Essa concepção, que legitima os princípios regulativos, será alargada por Nietzsche, e sua aplicação será estendida a todo tipo de pensamento.

O que me separa mais fundamentalmente dos metafísicos é isto: não concedo a eles que o 'eu' é aquilo que pensa: ao contrário, eu o tomo como uma construção

27 Como informa Lebrun, Kant usa o termo dialética em três acepções. A produção de um conhecimento falso sob a aparência de verdade; a crítica de uma tal sofística; um uso abusivo e não mais imitação fraudulenta da lógica. À primeira e à terceira concepções caberia então denunciar em que consiste a dialética, ao passo que à segunda cabe, uma vez tendo descortinado tal procedimento, fazer sua crítica. As duas primeiras concepções filiam-se à filosofia aristotélica, ao passo que a terceira é do próprio Kant. A denúncia kantiana da dialética consiste em demonstrar que ela existe quando "a Analítica transcendental cessa de ser uma Lógica da verdade, quando o entendimento puro faz 'uso hiperfísico' dos princípios que ali são legitimados 'fisiologicamente'” (Lebrun, 1993, pp. 67-68).

28 Cf. Nietzsche, 1967/1978, BM, § 4, KSA 5, p. 18. 
do pensamento, do mesmo nível de 'matéria', 'coisa', substância', 'indivíduo', finalidade', 'número': ou seja, apenas como ficções regulativas [regulative Fiktion], com ajuda das quais uma forma de estabilidade, e consequentemente 'cognoscibilidade', é introduzida em um mundo do vir-a-ser. A crença na gramática, no sujeito e objeto linguísticos, nas palavras que indicam atividade, subjugou os metafísicos até agora. O pensamento postula o eu: mas até agora se acreditou, como o 'povo', que no 'eu penso' repousa algo de uma certeza imediata e que esse 'eu' é a causa dada do pensamento, segundo cuja analogia 'entenderíamos' todas as demais relações causais. Tanto quanto habitual e indispensável possa ser agora essa ficção, isso nada prova contra seu caráter de invenção; algo pode ser condição para a vida e apesar disso ser falso. ${ }^{29}$

Com isso, juntamente com a crítica à cisão entre entendimento e sensibilidade, verdade e aparência, Nietzsche abole a diferença entre princípios constitutivos e regulativos. ${ }^{30}$ Além de gerar somente erros que nada são além de interpretações sobre o mundo, todas essas interpretações são ficções regulativas úteis à vida e atendem às necessidades daqueles que interpretam. Ao ampliar a concepção de erro no espírito da formulação kantiana, Nietzsche torna mais extensa a possibilidade contida na dialética. Nesta, só as doutrinas da alma, do mundo e de Deus, ou seja, os temas da metafísica especial psicologia, cosmologia e teologia racionais -, são considerados na análise sobre as inclinações naturais do homem. Nietzsche vai além, pois, em sua concepção do conhecimento como erro, interpretação e perspectiva, tudo aquilo que Kant exclui da esfera da investigação filosófica torna-se agora legítimo porque é uma ótica-de-perspectiva importante para a vida. No mesmo movimento de ampliação e nivelamento dos erros, porque não visa apenas aos temas clássicos da metafísica dogmática, Nietzsche vai afirmar que não só a

29 Nietzsche, 1967/1978, "Fragmento póstumo" 35 [35] de maio-julho de 1885, KSA 11, p. 526.

30 Num artigo em que analisa a apropriação que Nietzsche faz da filosofia de Kant, Tsarina Doyle aborda como a literatura acerca desse relacionamento gira essencialmente em torno de temas como o de coisaem-si e realidade e aparência, desconsiderando sempre o tema dos princípios constitutivos e regulativos. Ela afirma que a relação de Nietzsche com o criticismo se filia em grande parte por esse caminho, uma vez que ele procurou tornar prático todo o programa kantiano por meio da supressão da divisão entre teórico e prático. Assim, analisando a teoria do conhecimento kantiana, ela diz que para Nietzsche a consideração apenas das formas a priori leva a filosofia crítica a um impasse, pois, à medida que a experiência só integra esse programa pelo que nela é forma, temos que ou onde haja conhecimento não pode haver experiência ou onde haja experiência não pode haver conhecimento. Assim, Nietzsche conclui que o criticismo de Kant só pode conduzir ao ceticismo porque o mundo é expulso da possibilidade do conhecimento. A fim de reparar essa fissura teórica, os princípios regulativos teriam ainda um papel positivo, ainda que neles só os problemas do racionalismo clássico tivessem lugar. A solução que Nietzsche encontra para escapar a esses impasses é, assim, conceber que o intelecto só dispõe de ideias regulativas, daquelas ficções úteis. Nesse sentido, só mesmo a ideia contida numa razão prática conduzida por princípios regulativos pode desviar-se do ceticismo a que conduz a ideia de uma razão teórica (Cf. Doyle, 2004, pp. 180-204). 
metafísica, mas a ciência, a religião e a arte estão assentadas nesses erros que são óticas de perspectivas úteis. ${ }^{31}$ Com elas, o homem pode confiar na vida.

"A vida deve infundir confiança": o problema, assim colocado, é descomunal. Para resolvê-lo, o homem tem de ser mentiroso já por natureza, precisa, mais do que qualquer outra coisa, ser artista. E ele o é: metafísica, religião, moral, ciência - tudo isso são apenas rebentos de sua vontade de arte, de mentira, de fuga da "verdade". ${ }^{32}$

Se o trabalho crítico de Kant limitou o alcance da razão e com ele pôs fim às ilusões metafísicas, a postura antidogmática que atravessa toda a obra de Nietzsche filia-se ao espírito combativo kantiano. Se Nietzsche julga que sua linguagem soaria ainda estrangeira porque, ao contrário da tradição filosófica, não julgava os erros e as aparências como sendo um problema para o conhecimento, mas são essenciais à própria vida, tal concepção já está presente em Kant, na medida em que ele defende o erro e aparência como inclinação natural da natureza humana, e, mesmo sendo descobertos, não podem ser extirpados. Teria sido esse o partido que Nietzsche tomou?

31 Lebrun demonstra como Kant teria sido o primeiro filósofo a dar um tratamento diferenciado ao problema do erro, de modo a resolver o que ele denominou de "trapaça ontológica", ou seja, uma tendência generalizada da filosofia clássica em reputar ao erro apenas um lapso, uma inconsistência psicológica. Deliberadamente, filósofos como Platão e Descartes escolheram exemplos cotidianos do senso comum a fim de explicar que é impossível o erro existir ou que ele não passa de um desequilíbrio entre a vontade e o entendimento, uma vez que aquela é infinita e este finito. E, toda vez que julgar além dos limites da capacidade do entendimento, o homem produzirá erros. Tal é o argumento cartesiano em favor da desconsideração da positividade do erro. Em Kant, o erro não é mais um descuido em relação à verdade, bastando que esse descuido seja reparado para que o erro se dissipe; ao contrário, Kant argumenta que o erro existe justamente devido à fragilidade do saber. Com isso, ele não deve ser buscado mais nos exemplos da vida quotidiana, mas no cerne da aparência metafísica, cujas teorias decidem sem antes perguntar quais os seus títulos. O erro torna-se, assim, uma inconsciência da indeterminação do conhecimento, detectado mais facilmente no ofício do filósofo do que no discurso comum. Kant teria, portanto, invertido o estatuto do erro, retirando-lhe o aspecto fácil da explicação psicologizante e explicando-o pelo princípio da aparência (uma ilusão natural da razão). Lebrun conclui que essa inversão kantiana retira da filosofia, desde então, a necessidade de uma explicação psicológica, conferindo-lhe um outro tratamento que denuncia a sofística em que está envolvida a questão. Trata-se não só de refutar os erros, mas de encontrar-Ihes a fonte, ou seja, a aparência de onde surgem. Desde então, o erro não é um problema facilmente refutado, mas está incrustado no coração do conhecimento. "Há uma falsidade no coração do conhecimento, que não é acidental, assim como há, no homem, uma duplicidade inconsciente. [...] Depois de Kant, o erro deixa de ser uma inabilidade para tornar-se um destino. Sabese o partido que Nietzsche irá tirar dessa metamorfose". Infelizmente, o nome de Nietzsche aparece aí apenas como uma indicação, e o próprio Lebrun cessa a discussão sem nos apresentar o partido que Nietzsche tira da discussão (Lebrun, 2001, p. 23).

32 Cf. Nietzsche, 1967/1978, "Fragmento póstumo" 11 [415] de novembro de 1887-março de 1888, KSA, 13, p. 193. 


\section{Referências}

ALLISON, H. E. "Kant's Transcendental Idealism. An interpretation and defense". New Haven: Yale University Press, 2004.

ARISTÓTELES. "Poética". Tradução de Eudoro Souza. São Paulo: Nova Cultural, 1987. (Col. "Os pensadores").

CLARK, M. "Nietzsche on truth and philosophy". Cambridge: Cambridge University Press, 2002.

CRAWFORD, C. “The beginnings of Nietzsche's theory of language". Berlim/Nova York: Walter de Gruyter, 1988.

DOYLE, T. "Nietzsche's appropriation of Kant". In: Nietzsche Studien. 33. Berlim: Walter de Gruyter \& CO., 2004. pp. 180-204.

FOUCAULT, M. "Gênese e estrutura da Antropologia de Kant". Tradução de Márcio Alves da Fonseca e Salma Tannus Muchall. São Paulo: Loyola, 2011.

HABERMAS, J. "O discurso filosófico da modernidade". Tradução de Luiz Sérgio Repa e Rodnei Nascimento. São Paulo: Martins Fontes, 2002.

KANT, I. "Crítica da razão pura". Tradução de Manuela Pinto dos Santos e Alexandre Fradique Mojurão. Lisboa: Fundação Calouste Gulbenkian, 2001.

LEBRUN, G. "Kant e o fim da metafísica". Tradução de Carlos Alberto Ribeiro de Moura. São Paulo: Martins Fontes, 1993.

LEBRUN, G. "Do erro à alienação". In: Sobre Kant. Tradução de Rubens Rodrigues Torres Filho. São Paulo: Iluminuras, 2001.

LOPES, R. A. "Elementos de retórica em Nietzsche". São Paulo: Loyola, 2006.

MARQUES, A. "A filosofia perspectivista de Nietzsche". São Paulo: Discurso Editorial, 2003.

NIETZSCHE, F. "Sämtliche Werke". Kritische Studienausgabe (KSA). Org. Giorgio Colli e Mazzino Montinari. Berlim: Walter de Gruyter \& Co., 1967/1978. 15 vols.

NIETZSCHE, F. "Obras incompletas”. Tradução de Rubens Rodrigues. São Paulo: Nova Cultural, 1996. (Col. "Os Pensadores”). 